\title{
Bacillus butanolivorans sp. nov., a species with industrial application for the remediation of n-butanol
}

\author{
Nomeda Kuisiene, ${ }^{1}$ Juozas Raugalas, ${ }^{1}$ Cathrin Spröer, ${ }^{2}$ \\ Reiner M. Kroppenstedt ${ }^{2}$ and Donaldas Chitavichius ${ }^{1}$ \\ ${ }^{1}$ Department of Plant Physiology and Microbiology, Vilnius University, Chiurlionio 21/27, \\ Vilnius LT-03101, Lithuania \\ ${ }^{2} \mathrm{DSMZ}$ - Deutsche Sammlung von Mikroorganismen und Zellkulturen GmbH, Inhoffenstraße 7b, \\ 38124 Braunschweig, Germany
}

Correspondence

Nomeda Kuisiene nomeda.kuisiene@gf.vu.lt
Four bacterial strains, designated $\mathrm{K}^{\top}, \mathrm{K} 105, \mathrm{~K} 1012 \mathrm{~A}$ and $\mathrm{K} 101$, were isolated from soil in Lithuania. All these strains could use $n$-butanol as a sole carbon source. The strains grew in a medium containing 12-120 mM n-butanol. The strains were strictly aerobic, Gram-positive endospore-formers. The best growth was achieved at $25^{\circ} \mathrm{C}$ and $\mathrm{pH} 7.0$ in medium containing $1 \%(\mathrm{w} / \mathrm{v}) \mathrm{NaCl}$. The strains showed identical profiles of 16S-23S rRNA internal transcribed spacer PCR and nearly identical 16S rRNA gene PCR-RFLP electrophoretic patterns and physiological characteristics, demonstrating their relationship at the species level. The cellular fatty acid profile of $\mathrm{K} 9^{\top}$ consisted of significant amounts of the $\mathrm{C}_{15}$ branched-chain fatty acids iso- $\mathrm{C}_{15: 0}(16.78 \%)$ and anteiso- $\mathrm{C}_{15: 0}(45.80 \%)$. The diagnostic cell-wall diamino acid was meso-diaminopimelic acid. The 16S rRNA gene sequence of $\mathrm{K} 9^{\top}$ showed the highest similarity to the sequences of Bacillus simplex DSM $1321^{\top}$ and Bacillus muralis LMG $20238^{\top}$ (98.3 and $97.7 \%$, respectively). The DNA G+C content was 37.4 mol\%. Studies of DNA-DNA relatedness, morphological, physiological and chemotaxonomic analyses and phylogenetic data based on $16 \mathrm{~S}$ rRNA gene sequencing allowed strains $\mathrm{K}^{\top}, \mathrm{K} 105, \mathrm{~K} 1012 \mathrm{~A}$ and $\mathrm{K} 101$ to be described as members of a novel species of the genus Bacillus, for which the name Bacillus butanolivorans sp. nov. is proposed. The type strain is $K 9^{\top}\left(=\mathrm{DSM} 18926^{\top}=\mathrm{LMG} 23974^{\top}\right)$.
n-Butanol (1-butanol, butan-1-ol) is released into the environment from natural and anthropogenic sources. It is defined as a volatile organic compound. As such, n-butanol can contribute to the formation of photochemical smog when it reacts with other volatile compounds in the atmosphere. $\mathrm{n}$-Butanol present in the environment undergoes complex chemical reactions and may cause numerous indirect effects, particularly the formation of photochemical oxidants and their main constituent, ozone. High concentrations of ozone in the air can impair human health. Because of its potential health effects and influence on photochemical smog, removal of $n$-butanol from industrial waste streams is highly desirable (Veeranagouda et al., 2006).

\footnotetext{
Abbreviations: ARDRA, amplified rDNA restriction analysis; RISA, ribosomal intergenic spacer analysis.

The GenBank/EMBL/DDBJ accession number for the 16S rRNA gene sequence of strain $\mathrm{K}^{\top}$ is EF206294.

ARDRA and RISA profiles for the novel strains are available as supplementary material with the online version of this paper.
}

In a screening campaign aimed at isolating strains with the ability to tolerate high concentrations of n-butanol and to use it as a sole carbon source, strains $\mathrm{K}^{\mathrm{T}}$, K105, K1012A and K101 were isolated from soil sampled near the city of Klaipeda in Lithuania. The sampling depth was $0.02 \mathrm{~m}$. All the strains originated from two different samples. The strains were isolated on minimal medium (Arp, 1999) supplemented with a solution of microelements (Lageveen et al., 1988). n-Butanol (12 mM) was used as the sole carbon source. The isolated strains could tolerate 12$120 \mathrm{mM}$ n-butanol; $240 \mathrm{mM}$ was lethal to these strains. Strains $\mathrm{K}^{\mathrm{T}}$, K105, K1012A and K101 were further cultivated and maintained on nutrient agar.

For morphological characterization, the strains were cultivated at $25{ }^{\circ} \mathrm{C}$ on nutrient agar for $24 \mathrm{~h}$. Both the morphology of cells and the characteristics of colonies were investigated. Cell morphology was examined under an Olympus AX70 microscope (magnification $\times 1000$ ) and a JEM-100S electron microscope (magnification $\times 3000-$ $10000)$. For bright-field microscopy, cells were stained using Gram staining. For electron microscopy, cells were 
prepared as described by Mignot et al. (2001). The presence and morphology of endospores were checked in cells grown on nutrient agar for 2 weeks. Results of morphological characterization were identical for all the strains investigated and are given in the species description.

Genotyping experiments were repeated twice using different DNA extractions for amplification and different amplification products for restriction analysis. Results of these completely independent experiments were identical.

Ribosomal intergenic spacer analysis (RISA) was performed with primers S-D-Bact-1494-a-S-20 and L-D-Bact0035-a-A-15 (Daffonchio et al., 1998) as described by Kuisiene et al. (2002). RISA profiles were analysed by electrophoresis through $5 \%$ polyacrylamide gel. Strains $\mathrm{K}^{\mathrm{T}}$, K105, K1012A and K101 showed identical RISA profiles (see Supplementary Fig. S1, available in IJSEM Online). It can be concluded that strains $\mathrm{K}^{\mathrm{T}}, \mathrm{K} 105$, K1012A and K101 belong to a single species.

Amplified rDNA restriction analysis (ARDRA) was performed in order to investigate further the genomic diversity of strains $\mathrm{K}^{\mathrm{T}}, \mathrm{K} 105, \mathrm{~K} 1012 \mathrm{~A}$ and $\mathrm{K} 101$. Restriction analysis was performed with AluI, HaeII, HaeIII and TaqI as described by Kuisiene et al. (2002). Strain K1012A differed in a single band in the TaqI profile. The patterns of AluI, HaeII and HaeIII were identical for all the strains, confirming the close genetic relationship between these strains. Electrophoretic patterns of ARDRA are shown in Supplementary Figs S1 and S2.

All physiological assays were repeated three times. The temperature range for growth was determined in nutrient broth buffered with $50 \mathrm{mM}$ Tris/ $\mathrm{HCl} \quad(\mathrm{pH} \mathrm{7.0)}$ by measuring the $\mathrm{OD}_{600}$. In order to study the influence of $\mathrm{pH}$ on bacterial growth, the nutrient broth was buffered with citrate-phosphate buffer ( $\mathrm{pH}$ 6.0) and $50 \mathrm{mM}$ Tris/ $\mathrm{HCl}(\mathrm{pH} 6.5,7.0,7.5,8.0,8.5,8.8)$. Bacterial growth in buffered medium was monitored by measuring the $\mathrm{OD}_{600}$ using a Beckman DU-650 spectrophotometer. Most physiological tests were carried out using methods described by Claus \& Berkeley (1986). Cultures were incubated at $25{ }^{\circ} \mathrm{C}$ for $24 \mathrm{~h}$. The physiological characteristics were nearly identical for all the strains tested, confirming that strains $\mathrm{K}^{\mathrm{T}}, \mathrm{K} 105, \mathrm{~K} 1012 \mathrm{~A}$ and $\mathrm{K} 101$ belong to a single species. The strains differed in the following characteristics: hydrolysis of casein $\left(\mathrm{K}^{\mathrm{T}}\right.$ and K105 hydrolysed casein, while K1012A and K101 did not) and assimilation of myo-inositol, L-rhamnose and raffinose. Strain $\mathrm{K}^{\mathrm{T}}$ did not assimilate and strain K1012A grew weakly on these carbon sources. Results of the physiological characterization are given in the species description and in Table 1.

DNA extraction and amplification of the 16S rRNA gene were performed as described by Kuisiene et al. (2002). The $16 \mathrm{~S}$ rRNA gene PCR product was extracted from the agarose gel using a DNA extraction kit (Fermentas), and the purified PCR product was cloned into Escherichia coli
DH5 $\alpha$ using the InsT/Aclone ${ }^{\mathrm{TM}}$ PCR product cloning kit (Fermentas). Recombinant clones were detected through blue/white screening (Sambrook et al., 1989). Recombinant plasmid DNA was extracted as described by Birnboim \& Doly (1979).

Cloned $1.5 \mathrm{~kb}$ DNA fragments amplified by PCR were sequenced by automated DNA sequencing. 16S rRNA gene sequences were edited and sequence similarity was determined using the SEQBUILDER and MEGALIGN components of LASERGENE 6 (DNASTAR). The 16S rRNA gene sequences of the tested strains were aligned using the MEGA 3.1 program (Kumar et al., 2004); 1471 nucleotides were used for the alignment. A phylogenetic tree was constructed using the MEGA 3.1 program by the neighbourjoining method (Saitou \& Nei, 1987). The pairwisedeletion option was used. Bootstrap analysis of the neighbour-joining data, using 1000 resamplings, was carried out to evaluate the validity and reliability of the tree topology. The tree was rooted using the sequence of Brevibacillus brevis NBRC $15304^{\mathrm{T}}$ as an outgroup. The phylogenetic tree (Fig. 1) shows the phylogenetic position of strain $\mathrm{K}^{\mathrm{T}}$ among closely related species of the genus Bacillus.

The 16S rRNA gene sequence of strain $\mathrm{K}^{\mathrm{T}}$ was most similar to those of Bacillus simplex DSM $1321^{\mathrm{T}}$ and Bacillus muralis LMG $20238^{\mathrm{T}}$ (98.3 and $97.7 \%$, respectively). Sequence similarity with Bacillus asahii $\mathrm{MA}^{\mathrm{T}} \mathrm{1}^{\mathrm{T}}$ and Bacillus psychrosaccharolyticus ATCC $23296^{\mathrm{T}}$ was 96.1 and $95.4 \%$, respectively, indicating no relatedness between $\mathrm{K} 9^{\mathrm{T}}$ and any of them at the species level. Sequence similarity with other representatives of the genus Bacillus was below $95.0 \%$.

On the basis of $16 \mathrm{~S}$ rRNA gene sequence similarity, $B$. simplex DSM $1321^{\mathrm{T}}$ and B. muralis DSM $16288^{\mathrm{T}}$ were chosen for DNA-DNA hybridization experiments. For determination of $\mathrm{G}+\mathrm{C}$ content and for DNA-DNA hybridization, DNA was isolated by breaking cells in a French press, followed by purification by chromatography on hydroxyapatite according to the procedure of Cashion et al. (1977). The $\mathrm{G}+\mathrm{C}$ content of strain $\mathrm{K}^{\mathrm{T}}$ was determined by HPLC (Mesbah et al., 1989) as $37.4 \mathrm{~mol} \%$.

DNA-DNA hybridization was performed under optimal conditions $\left(2 \times \mathrm{SSC}\right.$ at $\left.63{ }^{\circ} \mathrm{C}\right)$ using a Cary 100Bio spectrophotometer. DNA-DNA relatedness of strain $\mathrm{K}^{\mathrm{T}}$ was $29.35 \%$ with B. simplex DSM $1321^{\mathrm{T}}$ and $28.75 \%$ with B. muralis DSM $16288^{\mathrm{T}}$. The results of DNA-DNA hybridization as well as those of phylogenetic analysis showed that strain $\mathrm{K}^{\mathrm{T}}$ belongs to the genus Bacillus, but represents a novel species within this genus.

Chemotaxonomic characteristics of strain $\mathrm{K}^{\mathrm{T}}$ were also in agreement with the properties of the genus Bacillus. The diagnostic cell-wall diamino acid was meso-diaminopimelic acid, determined as described by Schleifer (1985). Cells for cellular fatty acid analysis were harvested from $24 \mathrm{~h}$ cultures grown at $28{ }^{\circ} \mathrm{C}$ on tryptone soya agar. Fatty acids 
Table 1. Differentiating characteristics of strain $\mathrm{K}^{\top}$ and the phylogenetically most closely related species of the genus Bacillus

Reference species: 1, B. simplex (data from Heyrman et al., 2005 unless indicated); 2, B. muralis (Heyrman et al., 2005); 3, B. psychrosaccharolyticus (Priest et al., 1988); 4, B. asahii (Yumoto et al., 2004). +, Positive or $>85 \%$ of strains positive; v, variable (16-84\% positive); -, negative or 0-15\% of strains positive; w, weakly positive; v/w, variable and, when positive, weak; bv., biovar; NG, no growth; ND, no data available. All species were motile and negative for indole production.

\begin{tabular}{|c|c|c|c|c|c|}
\hline Characteristic & Strain $K 9^{\mathrm{T}}$ & 1 & 2 & 3 & 4 \\
\hline Sporangia swollen & - & - & $\mathrm{w}$ & + & - \\
\hline $5{ }^{\circ} \mathrm{C}$ & + & - & - & + & - \\
\hline $45^{\circ} \mathrm{C}$ & + & - & - & - & ND \\
\hline MacConkey agar & - & $+^{*}$ & ND & + & - \\
\hline $5 \%(\mathrm{w} / \mathrm{v}) \mathrm{NaCl}$ & + & $\mathrm{V}$ & + & $\mathrm{V}$ & - \\
\hline $7 \%(w / v) \mathrm{NaCl}$ & - & - & $\mathrm{w}$ & $\mathrm{ND}$ & - \\
\hline Catalase & + & + & + & $\mathrm{ND}$ & + \\
\hline \multicolumn{6}{|l|}{ Hydrolysis of: } \\
\hline Casein & - & $\mathrm{V}$ & $\mathrm{V}$ & + & + \\
\hline Starch & - & + & + & + & $\mathrm{w}$ \\
\hline Voges-Proskauer test & - & - & - & $\mathrm{V}$ & - \\
\hline \multicolumn{6}{|l|}{ Production of acid from: } \\
\hline Cellobiose & - & $-($ bv. 1$) ; \mathrm{v} / \mathrm{w}$ (bv. 2) & + & $\mathrm{V}$ & - \\
\hline Dulcitol & NG & - & - & - & ND \\
\hline Fructose & - & + & + & + & - \\
\hline Galactose & NG & - & + & - & - \\
\hline Glucose & - & + & + & + & - \\
\hline Lactose & NG & - & + & - & - \\
\hline Maltose & - & - (bv. 1); v/w (bv. 2) & + & + & - \\
\hline Mannitol & - & $\mathrm{v} / \mathrm{w}$ (bv. 1 ); w (bv. 2) & + & $\mathrm{V}$ & - \\
\hline Mannose & - & - & + & + & - \\
\hline \multicolumn{6}{|l|}{ Fatty acids ( $\%$ of total) } \\
\hline $\mathrm{C}_{16: 1} \omega 7 c$ alcohol & 5.79 & $2.97 \pm 0.74$ & $4.11 \pm 1.67$ & ND & $\mathrm{ND}$ \\
\hline iso- $\mathrm{C}_{16: 0}$ & 4.48 & $2.26 \pm 1.42$ & $1.61 \pm 1.00$ & ND & ND \\
\hline anteiso- $\mathrm{C}_{17: 0}$ & 2.72 & $1.82 \pm 0.80$ & $<1.0$ & ND & $\mathrm{ND}$ \\
\hline $\mathrm{G}+\mathrm{C}$ content $(\mathrm{mol} \%)$ & 37.4 & $39.5-41.8$ & 41.2 & $43-44$ & 39.4 \\
\hline
\end{tabular}

${ }^{\star}$ Data from Yumoto et al. (2004).

were extracted and analysed following the instructions of the Microbial Identification System operating manual (MIDI, 1999). In general, the fatty acid profile of strain $\mathrm{K} 9^{\mathrm{T}}$ was similar to those of $B$. simplex, B. muralis and $B$. asahii. iso- $\mathrm{C}_{15: 0}$ and anteiso- $\mathrm{C}_{15: 0}$ represent the main fatty acids of these species as well as numerous species within the bacilli. Strain $\mathrm{K} 9^{\mathrm{T}}$ contained a smaller amount of iso- $\mathrm{C}_{15: 0}$ and a larger amount of anteiso- $\mathrm{C}_{15: 0}$ than $B$. muralis and
B. asahii. $\mathrm{C}_{15}$ branched-chain fatty acids made up $62.58 \%$ of the total fatty acid content in strain $\mathrm{K}^{\mathrm{T}}$. This value was the lowest when comparing $\mathrm{K} 9^{\mathrm{T}}$ with $B$. simplex, B. muralis and $B$. asahii (Table 1). Larger amounts of $\mathrm{C}_{16: 1} \omega 7 c$ alcohol, iso- $\mathrm{C}_{16: 0}$ and anteiso- $\mathrm{C}_{17: 0}$ fatty acids differentiated between $\mathrm{K}^{\mathrm{T}}$ and the species listed above. The relative fatty acid concentrations are listed below in the species description. 


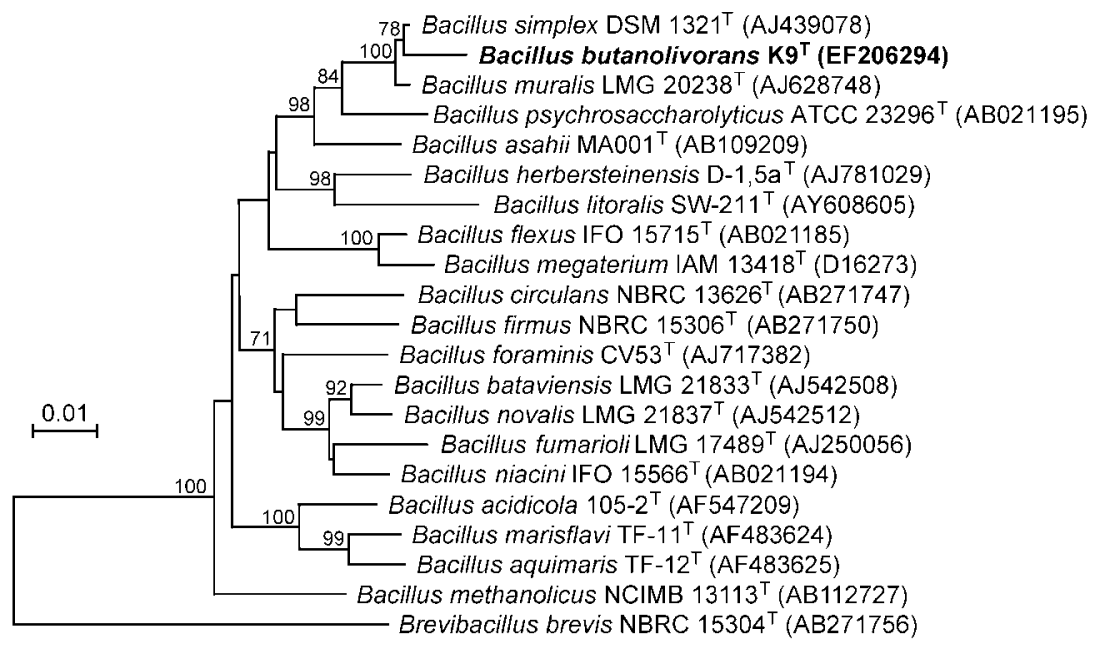

Fig. 1. Phylogenetic position of strain $K 9^{\top}$ among other Bacillus species on the basis of 16S rRNA gene sequences, determined by using the neighbour-joining method. Numbers at nodes represent percentage bootstrap values obtained from 1000 samplings. Only values greater than $70 \%$ are shown. Brevibacillus brevis NBRC $15304^{\top}$ was defined as the outgroup of the tree. Bar, 0.01 nucleotide substitutions per site.
On the basis of the above results, we conclude that strains $\mathrm{K}^{\mathrm{T}}, \mathrm{K} 105, \mathrm{~K} 1012 \mathrm{~A}$ and $\mathrm{K} 101$ represent a novel species of the genus Bacillus. We describe $\mathrm{K} 9^{\mathrm{T}}$ as the type strain of this novel species, for which we propose the name Bacillus butanolivorans sp. nov.

\section{Description of Bacillus butanolivorans sp. nov.}

Bacillus butanolivorans (bu.ta.no.li.vo' rans. N.L. neut. n. butanolum butanol; L. part. adj. vorans devouring, consuming; N.L. part. adj. butanolivorans butanol-consuming).

Gram-positive cells are rod-shaped and motile and occur in long chains and sometimes singly, varying in length from 2.5 to $5.1 \mu \mathrm{m}$ and in diameter from 0.8 to $1.3 \mu \mathrm{m}$. Oval central endospores are produced within unswollen sporangia. Colonies, grown for 2 days on nutrient agar at $25{ }^{\circ} \mathrm{C}$, are $2-4 \mathrm{~mm}$ in diameter, round, tawny, slightly raised and opaque. Strictly aerobic. The growth temperature range is $5-45^{\circ} \mathrm{C}$, with an optimum at $25{ }^{\circ} \mathrm{C}$. Growth occurs at $\mathrm{pH} 6.0-8.8$, with an optimum at $\mathrm{pH}$ 7.0. Growth is observed in the presence of $0.5-5 \%(\mathrm{w} / \mathrm{v}) \mathrm{NaCl}$, with an optimum at $1 \%(\mathrm{w} / \mathrm{v}) \mathrm{NaCl}$. Phenylalanine is not deaminated and growth in Sabouraud dextrose broth is negative. Arginine dihydrolase, lysine decarboxylase and ornithine decarboxylase reactions are negative. L-Arabinose is not assimilated; utilization of myo-inositol, raffinose and L-rhamnose is variable. The diamino acid in the cell wall is meso-diaminopimelic acid. The fatty acid profile consists of iso- $\mathrm{C}_{13: 0}\left(0.29 \%\right.$ in the type strain), iso- $\mathrm{C}_{14: 0}(8.77 \%)$, $\mathrm{C}_{14: 0} \quad(1.76 \%), \quad$ iso- $\mathrm{C}_{15: 0} \quad(16.78 \%), \quad$ anteiso- $\mathrm{C}_{15: 0}$ $(45.80 \%), \mathrm{C}_{15: 0}(1.33 \%), \mathrm{C}_{16: 1} \omega 7 c$ alcohol $(5.79 \%)$, iso$\mathrm{C}_{16: 0}(4.48 \%), \mathrm{C}_{16: 1} \omega 11 c(6.14 \%), \mathrm{C}_{16: 0}(2.97 \%)$, iso$\mathrm{C}_{17: 1} \omega 10 c(0.97 \%)$, iso- $\mathrm{C}_{17: 1} \mathrm{I}$ and/or anteiso- $\mathrm{C}_{17: 1} \mathrm{~B}$ $(0.94 \%)$, iso- $\mathrm{C}_{17: 0}(1.27 \%)$ and anteiso- $\mathrm{C}_{17: 0}(2.72 \%)$. Differentiating characteristics are indicated in Table 1 . The DNA G $+\mathrm{C}$ content of the type strain is $37.4 \mathrm{~mol} \%$.

Known strains have been isolated from soil. The type strain is $\mathrm{K}^{\mathrm{T}}\left(=\mathrm{DSM} 18926^{\mathrm{T}}=\mathrm{LMG} 23974^{\mathrm{T}}\right)$. In the characters for which a variable result was obtained, the type strain does not hydrolyse casein and does not assimilate myoinositol, L-rhamnose or raffinose.

\section{Acknowledgements}

We are grateful to Professor Dr H. G. Trüper (University of Bonn, Germany) for comments on the nomenclature of the novel species, to Dr P. Schumann (DSMZ) for G + C content analysis and to Dr Habil. J. Staniulis (Institute of Botany, Lithuania) for electron microscopy. We thank J. Gregor, G. Pötter and B. Sträubler (DSMZ) for their excellent technical assistance.

\section{References}

Arp, D. J. (1999). Butane metabolism by butane-grown 'Pseudomonas butanovora'. Microbiology 145, 1173-1180.

Birnboim, H. C. \& Doly, J. (1979). A rapid alkaline extraction procedure for screening recombinant plasmid DNA. Nucleic Acids Res 7, 1513-1523.

Cashion, P., Holder-Franklin, M. A., McCully, J. \& Franklin, M. (1977). A rapid method for the base ratio determination of bacterial DNA. Anal Biochem 81, 461-466.

Claus, D. \& Berkeley, R. C. W. (1986). Genus Bacillus Cohn 1872. In Bergey's Manual of Systematic Bacteriology, vol. 2, pp. 1105-1139. Edited by P. H. A. Sneath, N. S. Mair, M. E. Sharpe \& J. G. Holt. Baltimore: Williams \& Wilkins.

Daffonchio, D., Borin, S., Frova, G., Manachini, P. L. \& Sorlini, C. (1998). PCR fingerprinting of whole genomes: the spacers between the $16 \mathrm{~S}$ and $23 \mathrm{~S}$ rRNA genes and of intergenic tRNA gene regions reveal a different intraspecific genomic variability of Bacillus cereus and Bacillus licheniformis. Int J Syst Bacteriol 48, 107-116.

Heyrman, J., Logan, N. A., Rodríguez-Díaz, M., Scheldeman, P., Lebbe, L., Swings, J., Heyndrickx, M. \& De Vos, P. (2005). Study of mural painting isolates leading to the transfer of 'Bacillus maroccanus' and 'Bacillus carotarum' to Bacillus simplex, emended description of Bacillus simplex, re-examination of the strains previously attributed to 'Bacillus macroides' and description of Bacillus muralis sp. nov. Int J Syst Evol Microbiol 55, 119-131.

Kuisiene, N., Jomantiene, R., Valiunas, D. \& Chitavichius, D. (2002). Characterization of thermophilic proteolytic spore-forming bacteria 
from a geothermal site in Lithuania based on 16S rDNA RFLP and ITS-PCR analyses. Microbiology (English translation of Mikrobiologiia) 71, 712-716.

Kumar, S., Tamura, K. \& Nei, M. (2004). MEGA3: integrated software for molecular evolutionary genetics analysis and sequence alignment. Brief Bioinform 5, 150-163.

Lageveen, R. G., Huisman, G. W., Preusting, H., Ketelaar, P., Eggink, G. \& Witholt, B. (1988). Formation of polyesters by Pseudomonas oleovorans: effect of substrates on formation and composition of poly$(R)$-3-hydroxyalkanoates and poly- $(R)$-3-hydroxyalkenoates. Appl Environ Microbiol 54, 2924-2932.

Mesbah, M., Premachandran, U. \& Whitman, W. B. (1989). Precise measurement of the $\mathrm{G}+\mathrm{C}$ content of deoxyribonucleic acid by highperformance liquid chromatography. Int J Syst Bacteriol 39, 159-167.

MIDI (1999). Sherlock Microbial Identification System, Operating Manual, version 3.0. Newark, DE: MIDI Inc.

Mignot, T., Denis, B., Couture-Tosi, E., Kolstø, A.-B., Mock, M. \& Fouet, A. (2001). Distribution of S-layers on the surface of Bacillus cereus strains: phylogenetic origin and ecological pressure. Environ Microbiol 3, 493-501.
Priest, F. G., Goodfellow, M. \& Todd, C. (1988). A numerical classification of the genus Bacillus. J Gen Microbiol 134, 1847-1882.

Saitou, N. \& Nei, M. (1987). The neighbor-joining method: a new method for reconstructing phylogenetic trees. Mol Biol Evol 4, $406-425$.

Sambrook, J., Fritsch, E. F. \& Maniatis, T. (1989). Molecular Cloning: a Laboratory Manual, 2nd edn. Cold Spring Harbor, NY: Cold Spring Harbor Laboratory.

Schleifer, K.-H. (1985). Analysis of the chemical composition and primary structure of murein. Methods Microbiol 18, 123-156.

Veeranagouda, Y., Vijaykumar, M. H., Patil, N. K., Nayak, A. S. \& Karegoudar, T. B. (2006). Degradation of 1-butanol by solventtolerant Enterobacter sp. VKGH12. Int Biodeterior Biodegrad 57, 186-189.

Yumoto, I., Hirota, K., Yamaga, S., Nodasaka, Y., Kawasaki, T., Matsuyama, H. \& Nakajima, K. (2004). Bacillus asahii sp. nov., a novel bacterium isolated from soil with the ability to deodorize the bad smell generated from short-chain fatty acids. Int J Syst Evol Microbiol 54, 1997-2001. 